\title{
Komunikasi Matematik bagi Siswa di Sekolah Menengah Atas
}

\author{
Faizatul Mustajazah'; ${ }^{1}$ Rita Sari ${ }^{2}$ \\ ${ }^{1}$ mahasiswa PMA IAIN Langsa; ${ }^{2}$ Dosen IAIN Langsa \\ faizatulmustajazah@gmail.com, ritasari17@iainlangsa.ac.id
}

\begin{abstract}
Mathematical communication is a combination of understanding and doing mathematics. The purpose of this research is to review students' mathematical communication skills as measured through tests. The research method used was a survey method. The research sample is taken as a whole or referred to as total sampling. The data collection tool used in the form of a descriptive test was analyzed descriptively. The results of the data analysis showed that the mathematical representation ability of students included in the category of adequate or equal to $59.70 \%$, in the category of less than $40.29 \%$.
\end{abstract}

Keywords: Concept Mastery, High School, Mathematics, and Representation.

\begin{abstract}
Abstrak
Komunikasi matematik merupakan perpaduan antara memahami dan melakukan matematik. Tujuan dari peneltian ini adalah untuk mengulas kemampuan komunikasi matematik siswa yang diukur melalui tes. Metode penelitian yang digunakan adalah metode survei. Sampel penelitian diambil secara keseluruhan atau disebut sebagai sampling total. Alat pengumpul data yang digunakan berupa tes uraian yang dianalisis secara deskriptif. Hasil analisis data menunjukkan bahwa kemampuan representasi matematis siswa termasuk dalam kategori cukup atau sebesar cukup atau sebesar 59,70\%, dalam kategori kurang sebesar $40,29 \%$.
\end{abstract}

Kata Kunci: Matematika, Penguasaan Konsep, Representasi, SMA. 


\section{A. Pendahuluan}

Matematika berkaitan dengan konsep-konsep abstrak karena dimulai dari pengungkapan gagasan, struktur dan hubungan-hubungannya yang diatur secara logis, bersifat deduktif dan hirarkial (Gusniwati, 2015). Novaanggreni (2016) mengungkapkan penyebab siswa kurang menyukai matematika karena siswa menganggap bahwa (1) matematika merupakan pelajaran yang sulit, (2) bahasa yang digunakan untuk menyampaikan materi sulit dipahami, (3) suasana kelas saat belajar matematika menjadi menengangkan sehingga timbul perasaan tertekan dan takut, (4) guru matematika menyeramkan dan kurang menguasai konsep matematika, (5) serta penyajian pelajaran kurang menarik dan cenderung monoton. Sehingga dapat dipahami bahwa apabila siswa memiliki persepsi yang negatif terhadap pelajaran dan guru maka dapat diprediksi hasil belajarnya juga akan menurun. Oleh sebab itu menjadi penting bagi guru untuk melakukan sebuah inovasi dalam pembelajaran agar matematika dapat diterima dan disukai oleh siswa, seperti mereka menyukai pelajaran lain contohnya biologi dan olah raga.

Salah satu faktor penyebab siswa tidak menyukai pelajaran matematika seperti yang diungkapkan oleh Diah adalah bahasa yang digunakan oleh guru tidak dapat dipahami. Di sini terlihat pentingnya komunikasi dalam kelas. Komunikasi merupakan sarana penyampaian pesan dari guru kepada siswa melalui saluran tertentu dengan tujuan siswa dapat menerima dan memahami dengan baik maksud pesan yang disampaikan.

Komunikasi satu arah (one way communication) kurang mempertimbangkan keberadaan siswa akibatnya siswa merasa diabaikan dan tidak diperhatikan oleh guru. Seharusnya seorang guru membuat siswa merasa berharga dengan pelibatan dirinya secara aktif selama proses belajar mengajar. Kusmaryono \& Dwijanto (2016) menjelaskan bahwa pembelajaran matematika tidak sekadar proses penyampaian informasi saja, menampilkan rumus dan penyelesaian soal saja, namun lebih dari itu guru berperan sebagai mediator dan fasilitator serta membantu siswa untuk mengkonstruksikan pengetahuannya sendiri melalui nalar. 
Komunikasi dalam matematika berkaitan dengan kemampuan dan keterampilan siswa dalam berkomunikasi. Standar evaluasi untuk mengukur kemampuan ini adlaah dengan (1) menyatakan ide matematika melalui berbicara, menulis, demostrasi, dan menggambarkan dalam bentuk visual; (2) memahami, menginterpretasi, dan menilai ide matematik yang disajikan dalam tulisan, lisan atau visual, dan (3) menggunakan kosa kata/bahasa, notasi dan struktur matematik untuk menyatakan ide, menggambarkan hubungan, dan pembuatan model (Ansari, 2009).

Menurut Baroody, terdapat lima aspek komunikasi yaitu representasi (representation), mendengar (listening), membaca (reading), diskusi (discussion), dan menulis (writing). Representasi merupakan (1) bentuk baru sebagai hasil translasi dari suatu masalah atau ide; (2) translasi suatu diagram atau model fisik ke dalam simbol atau kata-kata. Sementara mendengar merupakan aspek penting dalam suatu diskusi. Siswa tidak akan dapat memberi pendapatnya apabila tidak mendengarkan dengan seksama topik yang sedang dibicarakan. Reading merupakan aktivitas membaca teks secara aktif untuk mencari jawaban atas pertanyaan-pertanyaan yang telah disusun. Keempat adalah diskusi, ada kalanya siswa mampu melakukan perhitungan (matematik) namun ia tidak mampu menjelaskan apa yang ditulisnya. Untuk itu diskusi perlu diatihkan. Karena diskusi merupakan sarana untuk mengungkapkan dan merefleksikan pikiran siswa. Terakhir adalah menulis. Menulis merupakan serangkaian kegiatan yang dilakukan dengan sadar untuk mengungkapkan dan merefleksikan pikiran. Menulis adalah alat yang bermanfaat dari berpikir karena melalui berpikir, siswa memperoleh pengalaman matematika sebagai suatu aktivitas yang kreatif.

\section{B. Metode}

Penelitian ini menggunakan metode penelitian survei (Sugiyono, 2018). Populasi penelitian adalah seluruh siswa kelas XI di Sekolah Menegah Atas Negeri 1 Bendahara Kec. Manyak Payed Kab. Aceh Tamiang yang berjumlah 67 orang. Sampel penelitian adalah keseluruhan populasi (Sari, 2017). Alat pengumpul data yang digunakan berupa tes hasil belajar berbentuk uraian. 
Analisis data yang digunakan menggunakan statistik deskriptif (Bungin, 2013).

\section{Hasil dan Pembahasan}

Pengumpulan data dilakukan dengan menyebarkan soal berbentuk uraian sebanyak enam soal. Hasil analisis data ditunjukkan pada tabel di bawah ini:

Tabel 1. Perolehan Tes Kemampuan Komunikasi Matematik

\begin{tabular}{|c|c|c|}
\hline No & Interval nilai & Frekuensi \\
\hline 1 & $31-38$ & 1 \\
\hline 2 & $40-48$ & 1 \\
\hline 3 & $49-57$ & 5 \\
\hline 4 & $58-66$ & 12 \\
\hline 5 & $67-75$ & 25 \\
\hline 6 & $76-84$ & 17 \\
\hline 7 & $85-93$ & 6 \\
\hline \multicolumn{2}{|c|}{ Total sampel } & 67 \\
\hline \multicolumn{2}{|c|}{ Jumlah } & 4706 \\
\hline \multicolumn{2}{|c|}{ Mean } & 70,239 \\
\hline \multicolumn{2}{|c|}{ Standar Deviasi } & 11,143 \\
\hline
\end{tabular}

Dari tabel 1 di atas diketahui jumlah sampel penelitian adalah 67 orang, dengan jumlah total perolehan tes kemampuan komunikasi matematik adalah 4706, dengan nilai mean (rata-rata) sebesar 70,239 dan standar deviasi sebesar 11,143. Nilai rata-rata perolehan siswa tersebut menunjukkan bahwa kemampuan rata-rata siswa dalam komunikasi matematis termasuk dalam kategori cukup. Berikutnya data pada tabel 1 dapat digambarkan melalui grafik batang di bawah ini: 


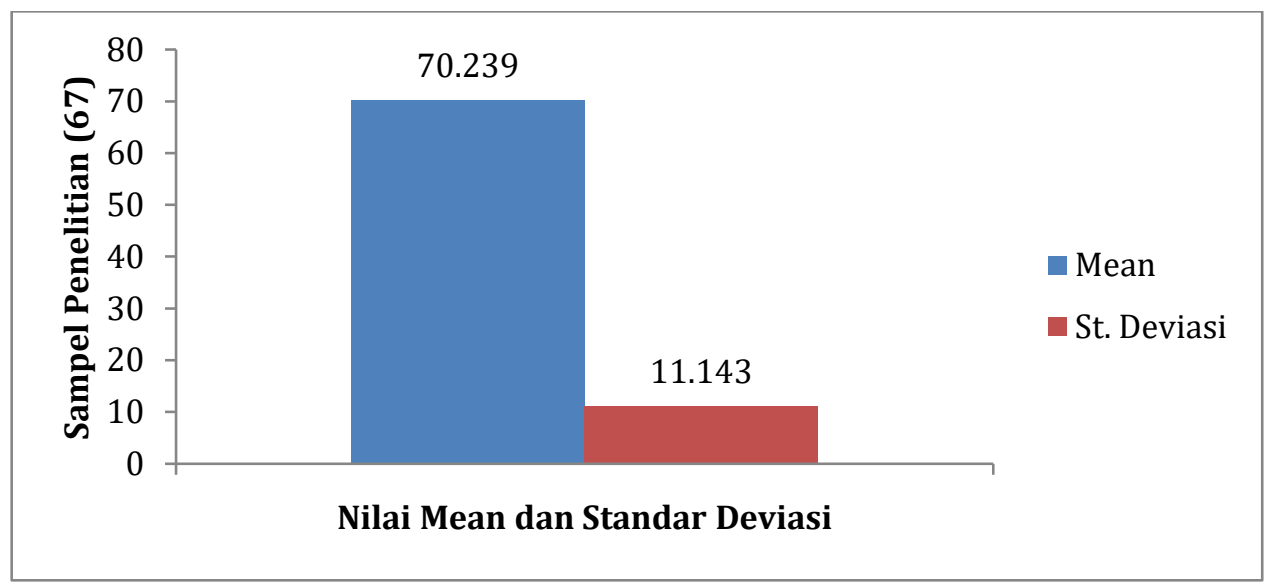

Gambar 1. Grafik Perolehan Nilai Rata-Rata (Mean) dan Standar Deviasi Tes Kemampuan Komunikasi Matematik Siswa

Selanjutnya dapat dijelaskan bahwa, kemampuan komunikasi matematik dari 67 orang dengan rincian sebagai berikut:

a) 40 orang memiliki kemampuan komunikasi matematis dalam kategori cukup $(59,70 \%)$

b) Sementara 27 orang $(40,29 \%)$ kemampuan komunikasi matematiknya berada pada kategori kurang.

Hasil ini menunjukkan bahwa, masih terdapat permasalahan dalam kemampuan komunikasi matematik siswa di sekolah ini karena masih terdapat 27 orang dengan kemampuan matematik dalam kategori kurang. Untuk lebih jelas hasil tes tersebut ditampilkan dalam bentuk histogram pada gambar 2. di bawah ini:

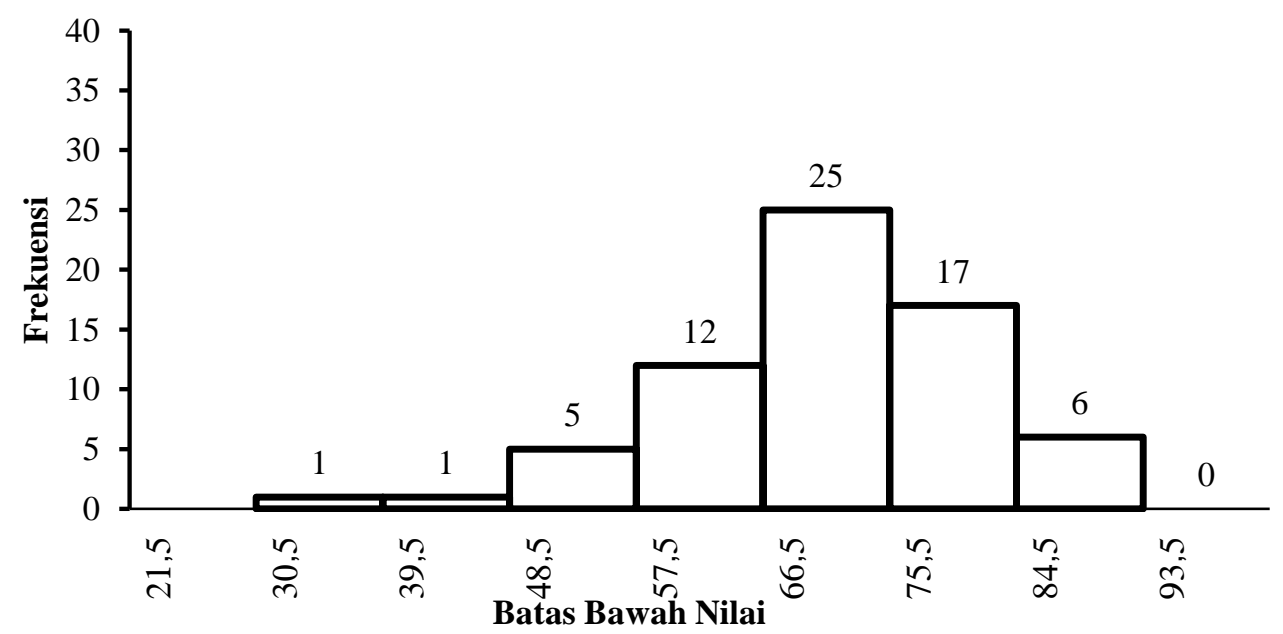

Gambar 2. Histogram Perolehan Nilai Tes Komunikasi Matematis 
Histogram di atas menunjukkan bahwa terdapat 1 orang yang memperoleh nilai pada rentang 30,5-38,5, 1 orang memperoleh nilai antara 39.5-47,5. Sebanyak 5 orang memperoleh nilai dalam interval 48,5-56,5, 12 orang dalam rentang nilai 57,5-65,5, dan pada rentang nilai 66.5-74,5 sebanyak 25 orang siswa, ada 17 orang memperoleh nilai 75,5-83,5. dan yang memperoleh nilai antara 84.5-93,5 sebanyak 6 orang. Dari hasil penelitian ini maka dianjurkan agar guru menggunakan berbagai metode pembelajaran yang lebih beragam, menciptakan suasana belajar yang ramah kepada siswa sehingga siswa merasa termotivasi dan senang dalam belajar matematika, membuat soal-soal yang tidak sekadar rutinitas saja namun memperhatikan dari kemampuan apa yang harus dimiliki siswa setelah belajar matematika. Sehingga

Masih rendahnya kemampuan komunikasi matematik yang diperoleh oleh siswa di SMA Negeri 1 Bendahara, disebabkan oleh beberapa hal, yaitu:

a) Keberadaan ekonomi siswa dari sekolah ini berasal dari ekonomi menengah ke bawah. Sebagian besar siswa harus bekerja sepulang sekolah, atau tidak bersekolah karena harus bekerja.

b) Keinginan untuk belajar juga rendah salah satu pemicunya karena mereka telah lelah ke sekolah setelah malamnya menjaga tambak.

c) Akibat sikap yang ditunjukkan siswa demikian, berimbas kepada guru, yang juga tidak merasa termotivasi mengajar, meskipun tujuan-tujuan belajar harus terpenuhi. Guru merasa iba dengan kondisi siswa mereka. Sehingga proses belajar di kelas tidak optimal sebagaimana tuntutan kurikulum.

Temuan hasil penelitian ini kiranya dapat ditindaklanjuti sebagai proses perbaikan pembelajaran khususnya pada mata pelajaran matematika. 


\section{Kesimpulan}

Kesimpulan yang diperoleh dari hasil penelitian ini adalah terdapat 40 orang memiliki kemampuan komunikasi dalam kategori cukup atau sebesar $59,70 \% .27$ orang mempunyai kemampuan komunikasi dalam kategori kurang atau sebesar 40,29\%.

\section{DAFTAR PUSTAKA}

Ansari, B. I. (2009). Komunikasi Matematik Konsep Dan Aplikasi. Banda Aceh: Yayasan PeNa.

Bungin, B. (2013). Penelitian Kuantitatif. Jakarta: Kencana Media Predana Group.

Gusniwati, M. (2015). Pengaruh Kecerdasan Emosional dan Minat Belajar terhadap Penguasaan Konsep Matematika Siswa SMAN di Kecamatan Kebon Jeruk. Formatif: Jurnal Ilmiah Pendidikan MIPA, 5(1), 26-41. https://doi.org/10.30998/formatif.v5i1.165

Kusmaryono, I., \& Dwijanto, D. (2016). Peranan Representasi Dan Disposisi Matematis Siswa Terhadap Peningkatan Mathematical Power. JIPMat, 1(1). https://doi.org/10.26877/jipmat.v1i1.1089

Novaanggreni. (2016). Kenapa Siswa Takut Matematika. Retrieved June 20, 2020, from https://www.scribd.com/document/330840147/KenapaSiswa-Takut-Matematika

Sari, R. (2017). Pengantar Penelitian Kuantitatif (1st ed.). Yogyakarta: Deepublish.

Sugiyono. (2018). Metode Penelitian Kuantitatif, Kualitatif, dan R\&D. Bandung: Alfabeta. 
